\title{
Financial Problems among Farmers in Malaysia: Islamic Agricultural Finance as a Possible Solution
}

\author{
Muhammad Hakimi Mohd Shafiai ${ }^{1}$ \& Mohammed Rizki Moi ${ }^{1}$ \\ ${ }^{1}$ Faculty of Economics and Management, Universiti Kebangsaan Malaysia, Bangi, Malaysia \\ Correspondence: Muhammad Hakimi Mohd Shafiai, Faculty of Economics and Management, Universiti \\ Kebangsaan Malaysia, Bangi, Malaysia. Tel: 60-13-529-7984. E-mail: hakimi@ukm.edu.my
}

Received: April 30, $2014 \quad$ Accepted: December 5, $2014 \quad$ Online Published: January 14, 2015
doi:10.5539/ass.v11n4p1
URL: http://dx.doi.org/10.5539/ass.v11n4p1

\begin{abstract}
This paper attempts to look at the possibility of collaboration of Islamic agricultural finance in agricultural land development realizing the farmers' financial problems during the case study and the government efforts in invigorating agricultural sector in Malaysia. Agricultural product and Loss Sharing (aPLS) which based on the contracts of al-muzara'a and al-musaqa from Islamic jurisprudence, partnership between the landowner and the farmer in brief, was highlighted in this paper. Agro Bank has the potential to employ Islamic agricultural finance realizing its roles in developing agricultural sector in Malaysia and its direction to be a full-fledged Islamic bank. The case study was carried out based on two methods that are interviews and questionnaire. These two methods have been used among the farmers under the one-off subsidy program by the Department of Agriculture in the selected six states in Malaysia. It was found that the farmers at the survey areas faced the financial problems during the second cycle cultivating yet the farmers have the capability in saving at the financial institutions. Thus, the main theme of this paper is that how Islamic agricultural finance can play a positive role and possible solutions to the farmers in Malaysia and eventually promoting agricultural development in Malaysia.
\end{abstract}

Keywords: Islamic agricultural finance, agricultural product and loss sharing (aPLS), farmers' lives in Malaysia, the department of agriculture (DOA), agro bank and agricultural land development

\section{Introduction}

The agricultural sector works in an environment of its own. This sector is vulnerable to many natural risks such as droughts, floods, and also attacks from wild animals, and these need to be taken into account by the farmer and the landlord. Due to these risks, financiers are reluctant to invest or finance this sector. Comparatively speaking, these risks are not common in industry, trade, services, and other sectors. Structurally, agricultural projects in Malaysia are often in the form of small holdings owned by families and households in rural areas. Private ownership is, by and large, the predominant attribute in the ownership of properties and assets. Most of these small-scale agricultural and non-agricultural enterprises are left to themselves. They have limited capacity to generate revenues beyond the equivalents of subsistence needs of the families. This is a reflection of the production capacity which is small and depends on the immediate needs of the household in the rural sector. Therefore, the asset holdings and products of these agricultural activities are not amenable to market transactions.

In Malaysia, even though agricultural markets are free arenas, there are certain inflexible elements such as government subsidies and support programs in which we find direct interference from the government in the market mechanism, prices and resource allocations. This can be seen through the direct participation of the Department of Agriculture in Malaysia in supporting farmers in developing agricultural land. Nevertheless, even the farmers in Malaysia got significant aids from the governments, due to some unavoidable reasons; they faced some problems in cultivating their agricultural land especially from financial perspectives. This is proven through the case study which has been done in selected states in Malaysia.

In the meantime, Islamic financial principles theorized that the economy will be more stable due to integration of financial and real sectors. Islamic banks would participate in real sector economic operations and if they chose projects carefully their profit share would also higher than the traditional interest rate. This is because, according to the early theories among Islamic economists, the growth of money must go with the real growths of the economy. In addition, the most important feature of Islamic banking and finance is that it promotes risk-sharing 
between the provider of funds (investor) and the user of funds (entrepreneur) through partnership contract. Besides that, Shari'a compliant finance was designed to enable Muslims to buy financial products that comply with the tenets of their religion. Just as non-Muslims do, Muslims require banking services like savings accounts, financing for education, home loans and many other services which banks offer their customers.

Furthermore, history from the establishment of Tabung Haji in Malaysia in 1962 to the present day has proven the great need for Shari'a compliant banking or financial products in rural communities. Thus, Islamic financial institution needs to cater to the desires of the community and to contribute effectively to economic development of Muslim countries and communities. In addition, Islamic finance also has to offer possible solution in developing Muslim communities. Therefore, this paper attempts mainly to highlight the farmers' lives in Malaysia and their challenges in developing agricultural land. Based on the problems faced by farmers particularly in financial aspects, Islamic solutions are proposed to be considered by the governing bodies. Apart from that, this paper also illustrates the potential of Agro Bank in Malaysia to be a central institution in offering Islamic agricultural finance for farmers.

\section{General Framework of Agricultural Sector in Malaysia}

\subsection{Agricultural Contract among Farmers in Malaysia}

In most cases, from the landowner's perspective, the types of land tenure can be seen in the Figure 1 which is based on the research by Donaldson (2000). According to him, firstly, the landowner must decide whether to work the land himself or to allow someone else to work it for him. If the landowner chooses the latter, then he has a further decision to make, either hiring a labour to cultivate the land for him and pay as a wage for his services or leasing the land to a tenant with the payment of a rent. Accordingly, the landowner was dealing either in form of wage or rent. For the both cases, the landowner has to decide either the methods of payment in the fixed sum or as a share of the crop. If he selects to pay the wage or rent in the fixed sum, he will engage a fixed wage labour or in a fixed rent tenant. However, in the case of crop sharing, the landowner will deal with sharecropping contract.

Furthermore, Huang (1975) described that there are three types of landlord-tenant relationship: (1) a fixed-rental contract, where the tenant pays the landowner a fixed amount, either in cash or kind/output; (2) a sharecropping contract, where the tenant pays the landowner a share; and (3) a hired-labour wage contract, where the landowner hires labour at a given wage rate. In addition, these main three types of contracts have their different degrees of risk. For fixed-rental system, the entire risk burden falls on the tenant, while under a hired-labour, it falls in the landowner. Sharecropping facilitates risk sharing and is a compromise between two extremes but it has been criticized as an inefficient tenancy in agriculture.

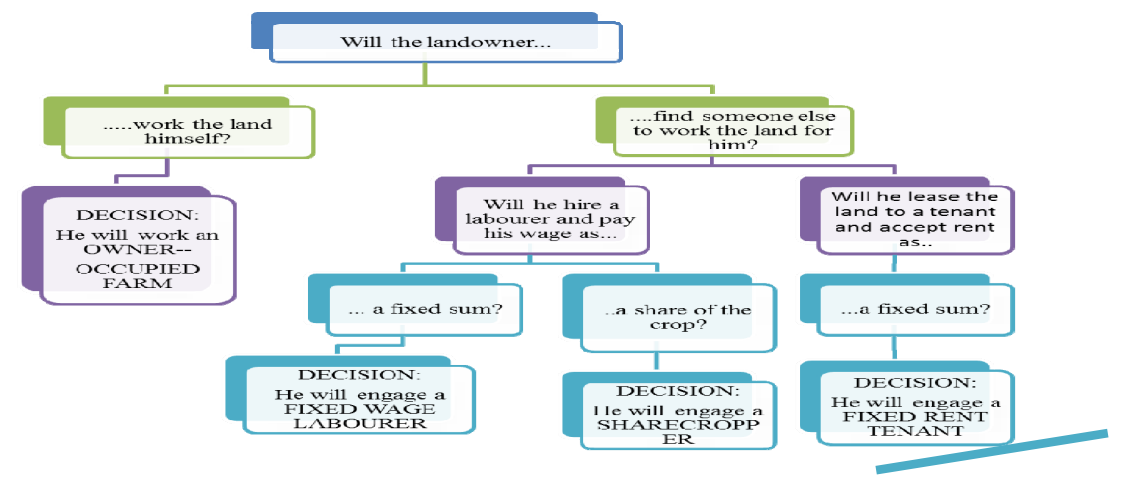

Figure 1. Schematic illustration of types of land tenure as viewed from the landowner's stance

Source: Donaldson (2000, p. 21)

According to Fredericks and Wells (1978), it can be stated that the tenancy system prevailing in most countries of Southeast Asia. The proportion of tenants and sharecroppers in the total agrarian population is high and a sizeable percentage of farmland is worked tenants and sharecroppers. They also argued that the urgency of land reform is less acute in Malaysia since the large-scale development and settlement programs have been done well by the government.

As for Malaysia, Senftleben (1976) found that there are five basic types of tenancy agreements between farmers and landlords are found in Malaysia. It can be explained as: 
1) Fixed rents (Sewa): Payable in kind or cash and is most common in the West Coast states. Cash rents are payable in advance before cultivation begins or rents in paddy after the harvest, but regardless of the actual yield or the current of paddy. This contract is usually renewed annually.

2) Crop sharing (Pawah): Landlord and tenant agree to share the crop according to a fixed ratio. This system prevails in the East Coast of Malaysia. For paddy, the landlord's share ranges from $30 \%$ to $70 \%$. The crop sharing system is also common in rubber holdings where the latex is shared on a 50 to 50 basis.

3) Lease (Pajak): Long term tenancy agreement. The farmer usually pays a lump sum of cash in advance to cover a longer period (usually between 3 and 5 years) which gives him extra security of tenure. A modification of this system is the restricted lease which reserves the landlord the right to terminate the agreement by refunding a portion of the sum advanced.

4) Usufructuary Loans (Gadai): The landlord temporarily transfers the usufructuary but the proprietary rights to another person in return for a loan. The agreement continues until the money repaid. Usufructuary loans are not registered with the authorities.

5) Usufructuary Mortgage (Jual Janji): The landlord agrees to pledge the property rights to his land as security for the repayment of a loan at the end of a specified period. If the loan is not repaid within the time limit, the debtor loses the right to redeem the property.

Meanwhile, according to Haughton (1983), the main systems of land rental in Malaysia are:

1) Sewa: Cash rental by season at a fixed rental rate.

2) Pajak: Renting for a fixed time period of more than a year.

3) Pawah: in-kind rental by season.

4) Bagi-Dua: Sharecropping with a 50:50 split between landlord and tenant.

5) Bagi-Tiga: Sharecropping where one third of the crop goes to the landlord.

In the rice planting, Selvadurai (1972) pointed out that a high incidence of tenancy in the paddy sector in Malaysia is prevailing. It has been estimated that only $48 \%$ of paddy farmers are full owners while $52 \%$ of paddy land is rented out in some form such as cash rentals, fixed paddy rentals, crop sharing or leasing. In addition, Horii (1972) found that in the rice-planting villages of the Malay Peninsula, the land tenure system based on kinship tends to be more dominant than a tenure system growing out of direct community relations. Research by Horri (1972) confirmed that kinship relation between landowners and tenants had priority in the land tenure system at the survey areas (villages in Kedah). The farmers, if possible, would first get agricultural land from the relatives in the same village and when that was not possible, they would go to relatives in other villages to find land.

On the other hand, in the rubber planting, Chew (1991) mentioned that the most common tenure arrangement between tappers and landowners of rubber smallholdings in Peninsular Malaysia is the share contract or share tapping. This contract means a share tapper is a tenant who has contracted the right to tap the trees for a certain percentage of the output, like the tapper may get $40 \%$ of the dry rubber-content and the landowner get remaining $60 \%$.

\subsection{General Overview of Agricultural Land Development in Malaysia}

Malaysia is endowed with relatively prosperous land and natural resources. Therefore, in Malaysia, agricultural sector was a major contributor to the economic growth until 1990. With the shift economic strategy towards industrialization since the middle 1980's, investors have a tendency to invest more in industries rather than agriculture, resulting in the declining share of the agricultural sector in the Gross Domestic Product (GDP) of the country. The government has declared in the Ninth Malaysia Plan (2006-2010) that the agricultural sector will be invigorated to become third engine of growth next to services and manufacturing sectors. Agricultural sector is back on the government agenda because of new understanding that growth in agricultural sector plays a major role in overall growth and poverty reduction through linkages to manufacturing and services in supply chain and international trading network. Regarding the agricultural commodities, Malaysia has produced and concentrating on the palm oil, rubber, rice, tropical fruit and coconut (The Economic Planning Unit, 2006). Moreover, Wong (2007), has argued that he role as an vital engine of growth is not only focusing on the production of oil palm, rubber, livestock and fisheries, but also the economic activities in their entire supply chains which can be say from inputs to final consumer or 'from seed to shelf'.

Based on the statistic in 2006-2007, Malaysia has a land areas around 33 million hectares. In terms of 
agricultural land use in Malaysia, it was found that almost $20 \%$ or approximately 6.6 million from the total areas are using for agricultural sector. This number is increasing from 5.9 million in 2000 and 6.38 million in 2005. This flow has been shown in Table 1 and it was observed that the areas for agricultural land are increasing significantly in Malaysia.

Table 1. Agricultural land use, 1980-2010 (Hectares)

\begin{tabular}{cc}
\hline Year & Total Area \\
\hline 1980 & 4379535 \\
1985 & 4952383 \\
1990 & 5546280 \\
1995 & 5743137 \\
2000 & 5949934 \\
2010 & 6383000 \\
\hline
\end{tabular}

Source: The Economic Planning Unit, various years

Furthermore, in Malaysia, the agriculture sector is usually common to rural areas which have the most arable lands. It can be seen through the Figure 2 which is most of crop operators located at the states like Sarawak, Sabah, Kelantan and Kedah where are numerous rural areas found there. As a result, theoretically, agricultural activities can be carried out to accomplish personal or family desires or even for profitable purposes. Thus, individuals' desires will promote the agriculture sector and impact to the rural economics.

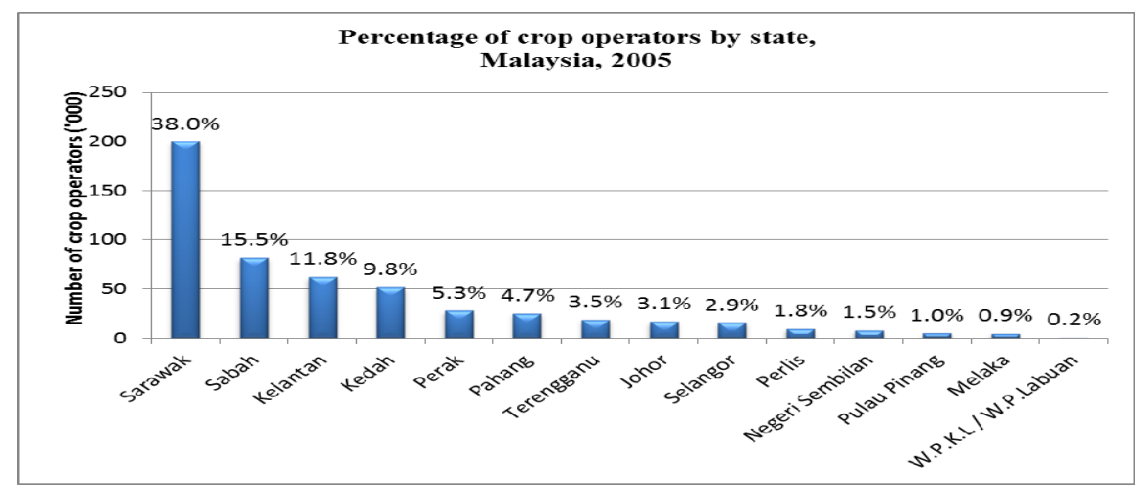

Figure 2. Percentage of crop operators by state, Malaysia 2005

Source: Department of Statistics, Malaysia

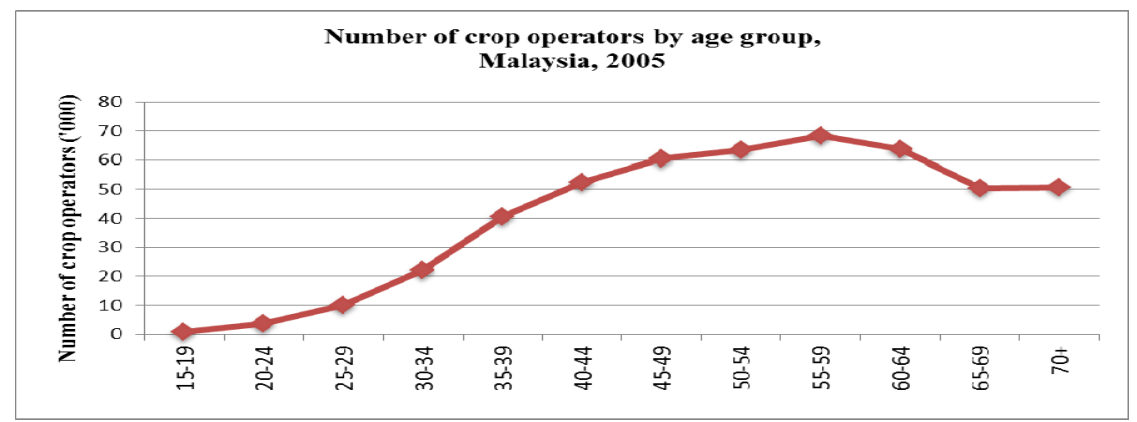

Figure 3. Number of crop operators by age group, Malaysia 2005

Source: Department of Statistics, Malaysia

The agriculture census 2005 identified a total number of 526265 crop operators. Sabah and Sarawak together accounted for more than half (53.5\%) of the crop operators in 2005 . This was followed by the east coast states of Kelantan, Terengganu and Pahang, contributing 20\%. Meanwhile the Northern states of Kedah, Perak, Perlis and 
Pulau Pinang together accounted $17.9 \%$. Kuala Lumpur and Labuan only cumulatively accounted for $0.2 \%$ of the total crop operators.

The agriculture census in 2005 showed that that $47.9 \%$ of crop operators were aged 55 and above while only $3.0 \%$ were aged 29 and below, indicating that generally young people were not interested in agriculture activities. The average age of the operators was 53 years. The census results also showed that $10.4 \%$ of crop operators were age 70 and above and are still active in cropping activities.

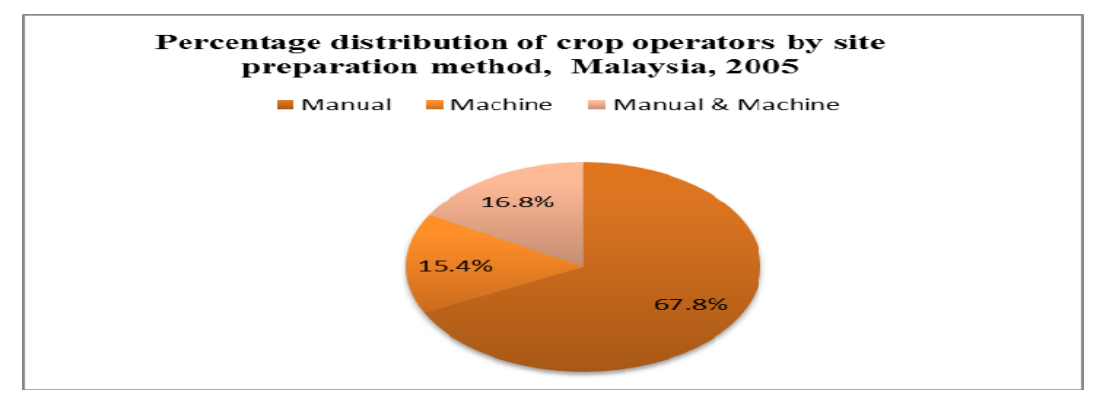

Figure 4. Percentage distribution of crop operators by site preparation method, Malaysia 2005

Source: Department of Statistics, Malaysia

Figure 4 portrays the different preparation methods that were used by the crop operators in Malaysia. The most prevailing method used in preparing land site for crop activities was the manual method (67.8\%). This shows that crop operators in Malaysia were less dependent on modern technology.

\subsection{Agricultural Finance in Malaysia}

\subsubsection{Agro Bank: Central Institution for Agricultural Sector in Malaysia}

According to Borhan and Ab Aziz (2009), in Malaysia, not all Islamic banks or Islamic windows of conventional banks are offering Islamic financing for the development of the agriculture sector. However, realizing the vital role of agriculture for the country, there are three banks that do provide Islamic financing for this sector, namely, Agro Bank, Bank Rakyat and Maybank Islamic Bank. Agro Bank can be considered as a leading bank with focus on the agricultural sector. This is because Agro Bank has 40 years of experience in agricultural banking and the bank's financing of the agricultural sector is driven by a policy set forth by the Ministry of Agriculture and Agro-Based Industries. Furthermore, this institution plays an important role as a development financial institution in enhancing the agricultural sector in Malaysia.

Agro Bank, previously known as Bank Pertanian Malaysia (BPM), was established by an Act of Parliament on September $1^{\text {st }}, 1969$ and commenced its operations on January $1^{\text {st }}, 1970$. As a statutory body, the Bank is in charge of arranging, providing, supervising and co-ordinating credit for agricultural purposes in Malaysia. The idea for an agricultural bank was the direct result of the government's decision to embark on the Muda Agriculture Project, a massive irrigation scheme for the rice bowl areas in the Muda Valley located in Kedah and Perlis in the northern part of peninsula Malaysia. The project is currently administered by Muda Agricultural Development Authority (MADA).

Financing for Muda project was provided by the World Bank. In its appraisal report, the World Bank highlighted the need for an institutionalized credit program to finance double cropping of paddies. The report recommended that a special credit scheme be devised to support the implementation of the project and to ensure the full realization of maximum economic and social benefits. BPM was thus established as a Rural Finance Institution to specialize in the provision of credit to the agricultural sector. In addition, Agro Bank is one of the institutions under the development financial institutions which represent the institutions established by the government to promote the development of certain identified priority sectors and sub-sectors of the economy, such as agriculture, infrastructure development and international trade. The institutions specialize in the provision of financing for projects in order to play a significant role in pursuing the aims of the government.

On April $8^{\text {th }}, 2008$, this bank changed its name to Agro Bank with regard to the corporatization process. The aim of this process was to strengthen Agro Bank's market position in the agricultural market and to expand the range of banking services to include the Small Medium Enterprise (SME) and retail markets. Therefore, the mission of Agro Bank now is to provide holistic financing according to market demands and customer needs through prudent financial management to Agro-entrepreneurs, micro, small and medium scale entrepreneurs and 
individuals. In terms of Islamic banking and finance growth in Agro Bank, the Head of Islamic Banking Division of Agro Bank, Muda (2010) mentioned that it has been offering Islamic products since 1996 and expects to be a full-fledged Islamic bank in 2015. Currently, Agro Bank finances the agriculture sector using Islamic principles such as Bay al-Inah, al-Bay Bithaman Ajil, and al-Rahn.

These three principles applied by Agro Bank are still forms of debt financing. Based on the theoretical framework suggested by Islamic scholars in developing the agriculture sector, partnership schemes of profit and loss sharing are better and more suitable for long term financing when compared to debt financing. Furthermore, harvesting in the agriculture sector is always related to the long term, while the principles which have already been applied by Agro Bank are more suitable for relatively short term of financing. Moreover, based on the interviews with the management officers of Agro Bank, the bank is not applying the products which are based on partnership or profit and loss sharing. However, there is a great potential for this type of product to be applied by Agro Bank if it is appropriately constructed to be both Shari'a compliant and suitable for the financial accounting of the bank. Therefore, constructing a framework for the application of Islamic partnership products for agricultural land development is crucial and much needed these days in Malaysia due to the demand from farmers and land owners.

\section{Farmers' Lives in Malaysia: A Case Study}

Basically, this section is based on case study approach. The data pertaining farmers' lives were collected during the case study in Malaysia from October to December 2010. Fundamentally, the farmer at the study areas goes through four different life-cycle stages, starting out as a small unit composed of a young couple, the proceed to have a number of children, grow up to be young adults and eventually set up their own households. In the last stage, the aging couple is once again alone. In each of these phases, resources, land and family labour are obligatory and allocated to agricultural production at different levels of amount and intensity in sequence to cover the family's changing consumption desires. Therefore, it can be assumed that the land and resources for peasant agricultural production and the family's reproduction are accessible as their needs change over time.

\subsection{Survey Areas}

In order to get clearer pictures of farmers' lives in Malaysia, a case study has been done among 138 farmers in 6 states of Malaysia from $1^{\text {st }}$ November until $9^{\text {th }}$ December 2010 as presented in Table 2.

Table 2. The schedule of case study in Malaysia 2010

\begin{tabular}{|c|c|c|c|c|}
\hline No. & Date of Case Study & State & $\begin{array}{l}\text { Number of } \\
\text { Farmer Involved }\end{array}$ & Type of Crops \\
\hline 1. & $\begin{array}{l}1^{\text {st }} \text { to } 5^{\text {th }} \text { November } \\
2010\end{array}$ & $\begin{array}{l}\text { Kelantan (North-East } \text { of } \\
\text { Peninsular Malaysia) }\end{array}$ & 27 & Banana, watermelon \\
\hline 2. & $\begin{array}{l}8^{\text {th }} \text { to } 11^{\text {th }} \text { November } \\
2010\end{array}$ & Sarawak (East Malaysia) & 23 & $\begin{array}{l}\text { Pumpkin, banana, pepper } \\
\text { and watermelon }\end{array}$ \\
\hline 3. & $\begin{array}{l}22^{\text {nd }} \quad \text { to } \\
\text { November } 2010\end{array}$ & $\begin{array}{l}\text { Johor (South of Peninsular } \\
\text { Malaysia) }\end{array}$ & 25 & $\begin{array}{l}\text { Banana, pineapple and } \\
\text { vegetable }\end{array}$ \\
\hline 4. & $\begin{array}{l}25 \& 26 \text { November } \\
2010\end{array}$ & $\begin{array}{l}\text { Negeri Sembilan (Western } \\
\text { Coast of Peninsular Malaysia) }\end{array}$ & 15 & Coconut, guava \\
\hline 5. & $\begin{array}{l}29^{\text {th }} \text { November to } 5^{\text {th }} \\
\text { December } 2010\end{array}$ & Sabah (East Malaysia) & 23 & Rice \\
\hline 6. & $\begin{array}{l}7^{\text {th }} \text { to } 9^{\text {th }} \text { December } \\
2010\end{array}$ & $\begin{array}{l}\text { Perak (North of Peninsular } \\
\text { Malaysia) }\end{array}$ & 25 & Banana \\
\hline
\end{tabular}

\subsection{Methods of Study}

In order to operationalize this study, the researcher had used two main means for data collection; interviews and questionnaire distribution.

\subsubsection{Interview}

One of the main techniques employed to get data in this research was in-depth semi structured interviews or can be said face-to-face interviewing with the officers at the Department of Agriculture in Malaysia and farmers at the selected survey areas. The researcher carried out 19 interviews with officers of the Department of Agriculture at the DOA headquarters in Putrajaya as well as the officers at the 6 states which is case study has been done. 
The DOA officers were interviewed with the intention to understand the policies, strategies and projects implementation in developing agricultural land. Finally, the interviews also have been done with the officers from the Department of Agriculture either at the headquarter office at Putrajaya as well at the states and district officers at the survey areas. As for farmers at the survey areas, in spite of through questionnaire, the semi structured interviews have been done with them. This is very important in order to obtain clearer information regarding farmers' lives in Malaysia. These interviews are also vital as a complement to the questionnaire.

\subsubsection{Questionnaire}

Since this research is based on a case study approach, the survey questionnaires totaling 138 were equally divided between the northern and southern regions of Malaysia as well as East Malaysia (Sabah and Sarawak). This questionnaire is consist of the detailed on agricultural land development by the respondents including, the size of farms, types of subsidies, income and form of contract. At the same time the details about financial capability, awareness of Islamic financial products for agricultural land as well as agricultural land issues were also accumulated.

The researcher had carried out by himself and this gave the opportunity to interview and to discuss in depth with the farmers regarding their daily lives as well as insightful issues related in this study. The data were collected during the months of November and December 2010 from the 6 main states in Malaysia which are Kelantan, Sarawak, Johor, Negeri Sembilan, Sabah and Perak. First, a questionnaire survey was carried out on a random sample of 138 farmers, concentrating on detailed agricultural land development including, the size of farms, types of subsidies, income and form of contract. At the same time the details about financial capability, awareness of Islamic financial products for agricultural land as well as agricultural land issues were also accumulated. Secondly, informal interviews have been conducted with the farmers concerning about their lives especially about in developing agricultural land and the problems raised from that. It also concern about their opinions particularly about their opinions about the financing from financial institutions.

\subsection{Findings}

In this section, case studies of selected farmers are presented in order to clarify and explain their actual life in developing agricultural land. However, in view of the limited time available and other constraints for the case study, the broad field of investigation narrowed down by limiting its level of analysis and geographical coverage.

From the case study, it was observed that the farmers who participate in the Department of Agriculture's scheme face three main issues, namely: issues from the farmers themselves, financing issues, and land status.

\subsubsection{Farmers' Issues}

It was observed in the survey areas that there are some tribulations in the farmers' lives in developing their idle agricultural land. Some of them are:

\section{1) Farmers' Status and Agricultural Contract Dealing}

The survey finds that 115 of farmers (83.3\%) in the survey area involved in the small scale of farming either they are in the self cultivation ( 81 respondents or $58.7 \%$ ) or renting land from landowner (34 respondents or $24.6 \%$ ). However, only $16.7 \%$ of respondents (23 farmers) recorded as large scale farmers or also known as agricultural entrepreneur. From the observation through the case study, it was found that self cultivation farmers and farmers who are renting agricultural land can be categorized as the small scale farmers. Therefore, the farmers in this scheme can be categorized into three types:

a) The farmer is also the landlord (self-cultivation);

b) The landlord rents his land to another party (small scale farmer) to develop it;

c) The landlord rents his land to a company/entrepreneur to develop it on a large scale and also known as agricultural entrepreneur.

In terms of the form of contracts for developing agricultural land, most of the farmers in the survey areas are involved in two types of contract either self-cultivation (81 respondents) or renting a piece of land from a landlord (51 respondents). Apart from this, it was observed that only about 5 farmers are involved in a partnership contract and a farmer involved in a special condition which is he cultivate land from a landowner without any compensation or payment and he will get all the output without allocate to the landowner.

2) Subsidy Program by the Department of Agriculture, Malaysia

The agricultural land project in these states was developed with full support and one-off subsidies from the Malaysian Department of Agriculture (DOA), as one of the vital agricultural government bodies. The subsidy 
programs by the DOA attempt to stimulate a specific type of production such as rice and other foods. These subsidy programs cover the purchase of modern inputs like chemical fertilizers, pesticides, and seeds. The aid is also directed towards investment in capital intensive needs such as farm machinery, irrigation systems, structural systems for land, and also land clearing, but the DOA does not give money to the farmers in the form of cash and aid is only given to help them start up.

3) Second Cultivating Cycle

For the second cultivating cycle, the DOA only monitors the agricultural projects and does not give any aid to the farmers, which means the farmers must plant and cultivate their land entirely on their own.

Consequently, through further interviews with farmers, it was found that some of the respondents were incapable of becoming independent during their second cultivating cycle since the DOA only subsidized their first cycle. As a result, some of the developed agricultural land became abandoned because of this situation.

\section{4) Consumption of Agricultural Output}

One of the most important finding through this case study is that most of the farmers in the survey areas, almost $82 \%$ of respondents or 113 farmers, consumed the output from their farm in huge amounts themselves, especially rice and watermelons. It was only 25 respondents are not consumed their crop because they sell it at all for the cash.

This means that the farmers deal with non-cash elements in their daily lives. Some of them did not use their money for their food because they would just take whatever they needed from their farm and yet they got an income from the same farm. Therefore, the non-cash elements among farmers are not calculated towards their annual income.

From the further investigation during the case study, the respondents are consuming their own agricultural output for their food. In addition, they are also engaged with small scale food production for personal consumption despite their commercial crops.

5) Age

Regarding the age of respondents in these projects, it was observed that the farmers who were selected in this scheme were mostly middle-aged and very few relatively were young involved in this agricultural project. From the case study, it can be stated that 101 respondents are at the range of 40 and up to 55 years old. From these numbers, it was observed that $37 \%$ or 51 respondents are at the range of 45 to 54 years old.

From the in depth interviews with respondents, most of them had experience in agricultural sector since they had been involved in farming from an early age. Conversely, it was only 27 respondents are below 40 years old and only 10 farmers are below 30 years old. This shows that Malaysian youth particularly in the survey areas doesn't seem to be interested in being involved in the agricultural sector.

\section{6) Type of Crops}

The majority of this project is devoted to cash crops such as bananas, pineapples, watermelons, and also vegetables in the selected research areas. Some of these farmers conducted rice farming (26 respondents) because their lands were selected as paddy land areas by the government. The farmers surveyed produce paddy, vegetables and fruits as recommended by the Department of Agriculture (DOA). Majority of the respondents have produce fruit which account for 90 farmers and only 22 respondents in vegetable cultivation. It was observed during the case study that almost all farmers involved in the cash or short-term crop like fruit and vegetable concerning the advices from the officers of the DOA. This is because the DOA only supports one-off subsidies to the farmers and therefore, it is crucial for farmers to harvest as soon as possible for the second cycle of farming.

The reason why the majority of the farmers are involved in cash cropping is because the Department of Agriculture strongly advises them to grow short term crops in order to gain the output or cash return in the shortest period and also due to their high marketability. As a result, they can use their returns for the second cultivating cycle since there are no subsidies for them from the DOA. However, from the interviews with farmers, there is some concern about the issue of the crops which are reflected in the government's policy like enhancing local supply on food. This is because the farmers cultivated cash crops during the first harvesting cycle but they were considering changing to permanent crops like rubber and palm oil. Therefore, in my opinion, this is not following the policy implemented by the government to encourage farmers to be involved in food production for food security.

7) Income and Life Sufficiency 
It was observed during the case study that most of the farmers at the survey areas got their monthly income at the range of RM1000 to RM2000. $64.5 \%$ of the farmers or 89 respondents are noticed at this range of income. Meanwhile, 21 respondents are at the range of RM2001-RM3000 and 14 of them at the range of RM3001-RM4000. Out of them, 14 respondents got their monthly income at the range of RM4001-RM5000 (7 farmers) and more than RM5001 (7 farmers). Consequently, it can be concluded that most of the farmers got their income relatively low but it was adequate for the necessary consumption like food and accommodation since they are staying at the rural areas which is comparatively lower than urban areas in terms of cost of living.

Moreover, for life sufficiency, it was found that 111 respondents or around $80 \%$ of the farmers who got full support from the DOA had an adequate annual income to bear or support their family. Meanwhile, 27 respondents who did not gain enough income through their agricultural activities, would supplement their income by working in the other entrepreneurial activities such as business, or handicrafts, or by doing a part time job such as a working as a security guard. Therefore, from this case study, it can be said that the range of monthly income among farmers was middle class are not so poor and not so rich. This is because the farmers at the survey areas are adequately have enough income to bear their daily expenses and also support their family.

8) Cooperation among Farmers

In Sabah, it was observed that the farmers who were engaged in paddy farming lacked cooperation among themselves. From interviews with the officer of the DOA Sabah, we learned that in order to avoid or reduce damage to the paddy fields by pests and birds, the farmers have to make their paddy land at the same moment as other farmers.

\section{9) Problems during Cultivation Process}

Regarding the agricultural problems which were faced by the farmers at the study areas, it seems that there are two major problems which are seed problems and wild animal threaten. For seed problem, 42 respondents or $30.4 \%$ complaining about this problem and for animal threaten, 34 or $24.6 \%$ respondents faced this problem. At the same time, a significant numbers of farmers faced agricultural problems in terms of pesticides and fertilizers which amounted around $18 \%$ or 25 respondents. These problems are appeared obviously like do not have access to improved farm inputs like seeds, fertilizers and pesticides during the second cycle cultivation.

In addition, many farmers (almost 60\%) in the survey areas have only a traditional approach to developing their land. They are also unorganized or do not keep records of their agricultural input and output transactions. For this reason, they fail to calculate their income or profit and face unpredicted problems which put them in trouble for the second cultivating cycle

\subsubsection{Agricultural Financing Issues}

\section{1) Deposit account}

From the case study, it can be stated that most of them (115 respondents) have a deposit account as compared those who did not have a deposit account with financial institutions (23 respondents). Therefore, it can be described that the farmers at the survey area have the ability to save. They have some savings either in the form of monetary savings or real assets. Regarding the reasons, why the farmers open their account with financial institutions, it was found that 78 respondents doing that because of safety reason. 14 farmers are expected to obtain the return or dividend form their saving and 15 of them had it because they got agricultural incentives from the government through the deposit account. Meanwhile, 8 farmers have a deposit account as a perquisite for the financing in developing their agricultural land from financial institutions.

Meanwhile, regarding the type of bank or financial institutions that the farmers at the survey areas deposit their money, majority of respondents ( 89 farmers) make their saving with Agro Bank or also known as agricultural bank among farmers in rural areas. 20 respondents are dealing with commercial banks and 5 respondents have their deposit account with government link financial institutions. However, only a respondent attached with Islamic bank.

\section{2) Islamic financing for agriculture}

For the Islamic financing survey among farmers in Malaysia, it can be described that there was not much knowledge of Islamic financing amongst farmers in the study areas. It was found that most of the farmers (around $71 \%$ from respondents or 98 farmers) were not aware of the existence of Islamic banking and finance for the agricultural sector. Meanwhile, 40 the respondents or $29 \%$ were aware about the existence but through in-depth interview with them, they are only familiar about Islamic finance for agriculture in brief and not comprehensively and in details. However, regarding the respondents' willingness to use Islamic financial 
products in developing agricultural land, it was observed that most of them, almost $74 \%$ or 102 respondents, were willing to apply Islamic financial product for the development of agricultural land.

Through in depth interviews with respondents, they were also concerned about the contract details of Islamic finance for agricultural land due to the lack of knowledge about Islamic financing among farmers. Therefore, it can be described that the farmers at the survey areas are concern and very careful regarding financial matters and endeavor to avoid interest-based financing. In addition, for the preferred modes of Islamic finance, the majority of respondents preferred to deal with mark-up sale of assets and the second favored is partnership financing. There is no big disparity between these two modes when 69 respondents were preferred to mark-up sale financing and 65 of them were favored to partnership financing. The less chosen by the respondents is lease financing which was favored by only a respondent and three of them desired to obtain cash financing from the Islamic financial institutions.

Through the interviews with farmers in detail, the mark-sale financing was most preferred because this type of financing was already well known among farmers in the rural areas. In addition, they are dealing repeatedly with many agencies to have agricultural assets or machines to assist them in harvesting process. For the partnership contract, the farmers at the study areas are hoping to have this type of financing with the Islamic financial institutions as active partner. However, partnership contract in agricultural sector is still less applicable in Malaysia and most of the institutions are reluctant to apply it.

Moreover, regarding the respondents' opinion on the advantages of Islamic banking financing in agricultural land development, it was found that 100 respondents or $72.5 \%$ are opined Islamic banking financing has the advantages and only $27.5 \%$ or 38 farmers saying there was no any exclusive features in Islamic banking financing for agricultural land development. In the meantime, from the 100 respondents who were mentioned that Islamic banking financing has the advantages, 85 respondents were concerned in terms of Shari'a compliancy in the Islamic financial products, 14 of them are opined that it was because of risk sharing elements and only a respondent said the advantages of Islamic banking financing is because of no collateral needed in the transactions. On the other hand, the reasons given by the farmers who mentioned that Islamic banking financing did not have advantages divided to two; more expensive thab conventional banking system (26 respondents) and complicated procedures in the Islamic banking system (12 respondents).

3) The lack of financial institutions for supporting farmers in developing their agricultural land and the reluctance of bankers.

It was also observed that farmers in Malaysia also have few interactions with financial institutions. A large amount of the farmers in the survey areas, about $91.3 \%$ of respondents or 126 farmers, didn't have any access or never deal with any formal financial institution for their land development. Nevertheless, they just get the aid from agricultural government bodies like the Department of Agriculture (DOA), Federal Agricultural Marketing Authority (FAMA), Lembaga Pertubuhan Peladang (LPP) and so on. On the other hands, only 12 farmers (8.7\%) have an experience to have a dealt for agricultural financing. It can be stated that, farmers at the survey areas have very low interaction with formal financial institutions in Malaysia even though they always faced financial problems during their second-cycle cultivation.

Based on the interviews with the farmers, their involvement with financial institutions in Malaysia is very low because of several factors:

a) Bankers are reluctant to give financing to small farmers.

b) The farmers are frustrated with the bureaucracy of the financial institutions.

c) The small farmers feel that the agricultural government bodies will give them support.

d) Fear among farmers about paying back a loan or financing from conventional financial institutions.

4) Informal financing: Loan from family members and landlords

There are different methods of mobilizing funds among the rural communities; one of them is through informal financing. In general, informal finance in rural areas in Malaysia has always been linked to social relations, economic and sometimes compassionate responsibility. From the thorough interviews made with the farmers at the survey areas, if they need financial aid, prefer to borrow from family members instead of formal financial institutions. This helps them the working capital requirement. According to them, informal financing is more flexible if they have problems with repayment. Therefore, there are significant numbers of farmers are actively involving in informal financing through loan from family members and landlords. 


\subsubsection{Land Issues}

1) Small size of landholding.

Regarding the size of the farms, most of the first and second categories involved in the DOA's schemes are rather small and most of them have only one hectare to two hectares. Meanwhile, the company or entrepreneur who is renting land from a landlord usually has a large area of more than 10 hectares and some of the entrepreneurs have more than 20 hectares. During the case study, it was observed that most of companies and entrepreneurs were found in the Negeri Sembilan and most of the small scale farmers were found in the rest of the selected states. In Sarawak and Perak for instance, most of the farmers in this scheme only have one hectare of agricultural land. Based on these facts, the farmers engaged with small scale land generally gained a small income as opposed to the large scale agricultural entrepreneurs.

2) Scattered Land Ownership.

Much of the land in Malaysia has been alienated on permanent titles, which confer rights according to land enactments. At the time of alienation, the land is normally held under a single ownership. However, over the years, Islamic and customary laws of inheritance, as well as the sale of land, have gradually given rise to the incidence of multiple ownerships and the fragmentation of land. This incidence also happened in the survey areas and this issue was also raised by the farmers. For example, in Sabah, it was found that Chinese farmers concentrate on large scale farming while Malay farmers just focus on small scale production and it was found that inheritance among Malay farmers contributed to this.

3) Status of land: from agriculture to another profit orientation such as industry and commercial housing.

It was observed that the land status of paddy land has been changed to other profitable activities like housing and industry by irresponsible people, especially in Sabah which has concentrated on activating idle paddy fields to manifest the government policy for food security. Therefore, based on an interview with the officer of the Department of Agriculture in Sabah, the farming system will be affected if the total areas for paddy cultivation are disturbed. It will affect the paddy irrigation system, reduce resistance to pests and also reduce the soil quality tremendously.

\section{The Analytical Results on the Farmers' Financial Issues in Malaysia}

Based on this case study in Malaysia which has revealed the real scenarios of farmers' lives, there are some alternative solutions from an Islamic perspective and in particular related to Islamic agricultural financing that can be highlighted here. Predominantly, through the case study, financial institutions in Malaysia should consider the daily life among farmers who are not necessarily involved in cash transactions. Many farmers in the survey areas did not use their money or cash for their daily food since they just ate from their own farm produce. It can be understood here that farmers' incomes from their farms is their real or net income.

Additionally, it can also be understood that agricultural economics is contrary to other economic activities like trade, commerce, manufacturing and construction which involve cash transactions. In addition, most financial institutions these days operate with some cash elements in their transactions. Therefore, agriculture's situation is opposite to other industries and the financial institutions should be concerned and alert about this matter in order to justify their financial management to the farmers.

From another sight, commercial banks have traditionally operated in the urban environment and provided short-term finance to firms and industries. They have very little experience of operating in the rural environment. Therefore, for Islamic financial institutions attempt to enter this field would require a lot of preparatory work by way of risk assessment, financial planning, operating procedures and monitoring arrangements as also strong legal support.

\subsection{Why Islamic Finance for Agricultural Land Development in Malaysia?}

\subsubsection{The Potential of Islamic Partnership Contract in Agriculture}

Siddiqi (1983) and Chapra (1992) have argued that Islamic banks will promote growth in Islamic countries by providing long-term financing to growth oriented sectors of the economy by using profit and loss sharing (PLS) contract or partnership financing which was closely related to the contracts of al-mudaraba and al-musharaka. It was envisaged that PLS became the core characteristic of Islamic banking financing. (Chapra, 1992; Siddiqi, 1983). Chapra (2002) also argues that more partnership or equity financing would enhance the stability characteristics of financial systems because, through the resultant risk-sharing contracts, financiers would have a greater incentive both to assess risks at the outset and to monitor borrowers after finance had been given (Chapra, 2002). 
Primarily, the partnership contract in the discussion on Islamic banking and finance is closely related to the principles of al-mudaraba and al-musharaka. On the other hand, there are also partnership contracts which were classified to be used in agricultural land development, namely al-muzara'a and al-musaqa. From the historical discourses, it was found that the earlier principles are related closely to trade transactions between a capital owner and a trader and the later are more related to an agricultural partnership between a landlord and a farmer. However, the principles of al-muzara'a and al-musaqa cannot be merely categorized as a similar to the scheme of Profit and Loss Sharing (PLS) based on the contracts of al-mudaraba and al-musharaka due to the difference in the nature of these contracts as PLS applies in trade while al-muzara'a and al-musaqa are more applicable in agriculture. Hence, al-muzara'a and al-musaqa principles can be described as the contracts which are based on sharing the product or output rather than sharing the profit and should be recognized as agricultural product and loss sharing (aPLS). This is can also be explained through the different types of capital in both schemes, money in PLS and land in aPLS that will shape the end of process of transaction, i.e. profit in PLS and agricultural output in aPLS.

\subsubsection{Agro Bank as a Prospective Institution}

Islamic financial institutions are supposed to take care of the issues and concerns highlighted above. Islamic banks in Malaysia, especially Agro Bank, can play a leading role in facilitating aPLS financing through become an active partner with farmers. Islamic banks can employ some of their own investment funds in aPLS. It is possible for a bank to have a share in the agricultural partnership with the farmers. For the agricultural entrepreneur, banks can provide agricultural financing since the entrepreneurs are usually involved in large scale farming and gain a large percentage of the agricultural output. For the individual farmer who is involved in small scale farming, the use of Islamic micro-credit instruments can be considered.

To be more precise, Agro Bank is expected to be a fully-fledged Islamic financial institution in Malaysia by 2015 focusing in offering financial aid to enhance agricultural land development. Furthermore, farmers at the survey areas were familiar and used with Agro Bank at least they have a deposit account at this institution. Therefore, Agro Bank has a high potential to be an Islamic bank in Malaysia which offering Islamic agricultural finance to farmers in developing agricultural land.

\subsubsection{Farmer's Capability in Saving at Financial Institution}

From the case study, it was found that the most farmers have a deposit account at the financial institutions. It can be inferred that the farmers have capability to save their money either in the small or huge amount. On the other hand, it is also found during the case study that some farmers are dealing with informal financing particularly through loan from family members or landlord. Therefore, Islamic financial institution has to provide a reliable financial structure to channelize funds into productive used. However, they need to attract farmers to make saving in their institution through promoting their Islamic financial products to the rural communities.

Moreover, in order to avoid scattered land ownership, the concept of share farming can be proposed here. The family members have to share with each other in developing their agricultural land. Another possibility is that they can give their land to other parties or farmers, if they have incapability, to develop it and they can share in the output based on aPLS or lease it based on the al-ijara principle.

\subsubsection{Financial Problems during Second Cycling Farming}

In terms of financing problems among farmers, particularly during the second cultivating cycle, the potential for the scheme of agricultural product and loss sharing (aPLS) based on the principles of al-muzara'a and al-musaqa can be proposed here. In this scheme, financial institutions in Malaysia which are offering Sharia' financial products like Agro Bank as a leading financial institution for agriculture, can be an active partner with the farmers and offering Islamic agricultural finance for farm inputs like seeds, pesticides and fertilizers realizing the major problems among farmers at the survey areas.

The bank and the farmer share the agricultural risk in return for the right of the agricultural profit or the product. This scheme also requires close supervision by the bank, builds confidence among the partners, and induces capital investment in agricultural land development. An Islamic financial institution is also required to establish operating procedures to ensure that no form of agricultural activity with farmers is outside the norms of Islamic principles and everything must be agreed by both parties. Apart from this, financing based on these Islamic schemes can also be done by non-financial institutions in Malaysia.

In addition, intervention by official agricultural agencies is really needed. Moreover, if the financial institution is applying aPLS and becomes an active partner with the farmers, the farming procedures will possibly be more appropriate. This is because all the procedures should be agreed upon at the outset among the contracting parties. 
As both the farmers and the financier have to comply with the agreement, this will make the farmers manage their agricultural land properly because in the aPLS scheme, rules and conditions concerning the type of crop, duration, land management, output sharing and termination of contract must be strictly followed.

\subsubsection{Islamic Financing Survey among Farmers}

From the survey, it can be described that the awareness among farmers on the existence of Islamic finance for agricultural land development were low, meanwhile, their willingness to employ Islamic financial products are high. In addition, the majority of farmers mentioned that Islamic finance has an advantage through offering Shari'a compliant financial products. Through in-depth interview, they are really concern and desire to the Islamic financial products and avoiding in interest based financing. Meanwhile, in terms of preferred modes of Islamic financing, the farmers are tend to employing mark-up sale financing for agricultural assets as well as partnership contract between Islamic bank and farmer.

\subsection{The Basic Framework of Agricultural Product and Loss Sharing (aPLS)}

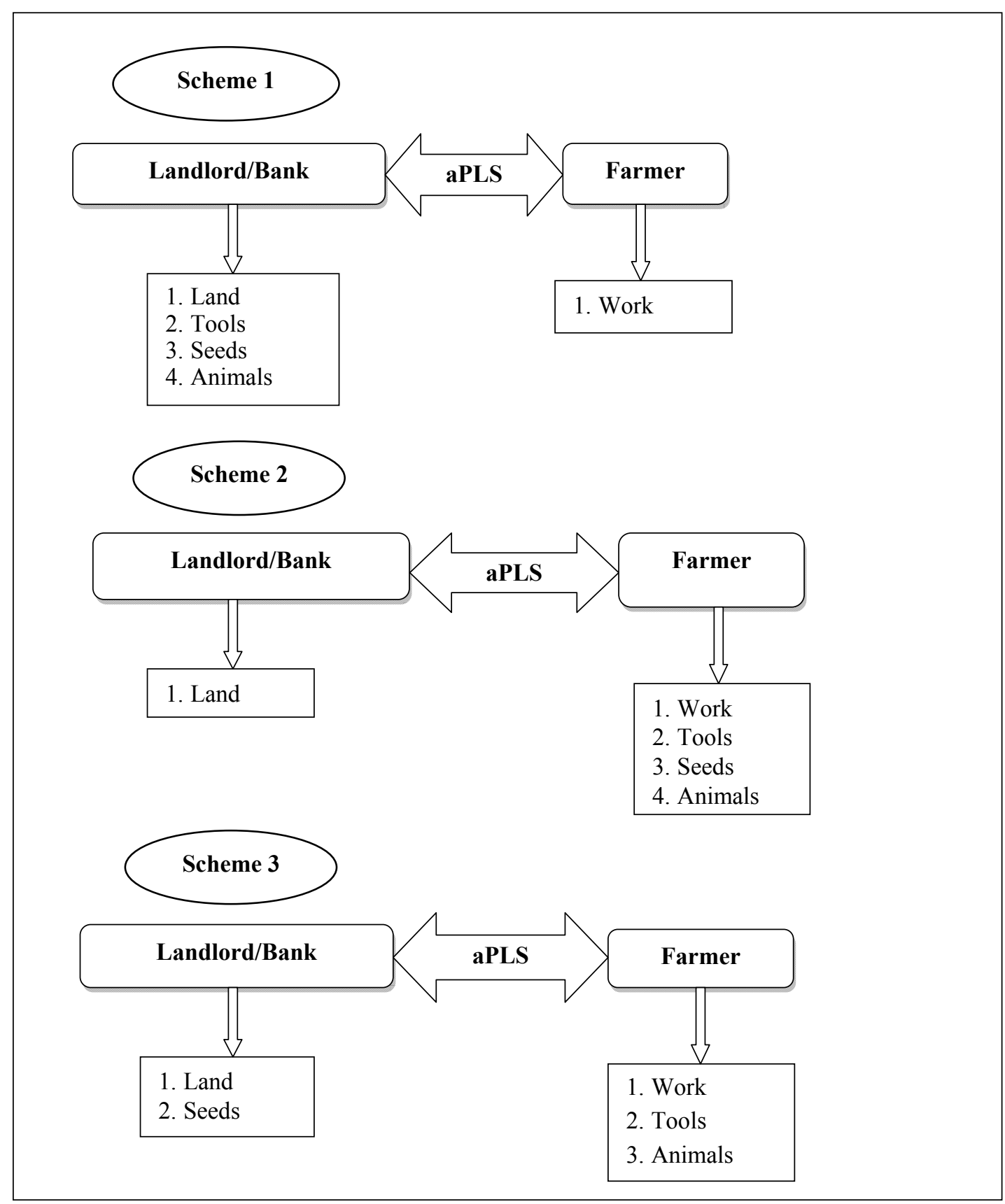

Figure 5. The feasible schemes of "agricultural products and loss sharing" (aPLS) between landlord / bank and farmer 
Basically, a financing arrangement based on al-muzar'a and al-musaqa or aPLS contract can be initiated subject to a joint partnership in the mobilization of land, other physical inputs and labor. For instance, Gulaid (1995) has classified how al-muzara'a can take various forms in financing. To begin with, a contract based on this principle might specify that the land and other physical factors of production for the partnership could come from one party while the labour could be supplied by the other party.

On the other hand, only the land might originate from one party while the other factors, including labor, could come from the other party in the contract. Yet, another alternative of al-muzara'a is that both the land and labour could come from one of the contracting parties, while all the other factors of production might be provided by the other party in the contract. Incidences of a three-party al-muzara'a partnership in which the first party provides land, the second provides a combination of required physical inputs, and the third provides labour, are common in contemporary agriculture.

Therefore, in this paper, using the forms of contract suggested by earlier Islamic scholars, the three schemes of aPLS as shown in Figure 5 are suggested here. First, the land, tools, seeds and animals are provided by the landowner and the work (effort) is undertaken by the tenant. Second, the land is provided by the landowner and the rest is provided by the tenant. Third, the land and seed is from landlord and the rest from the tenant.

From the banks' perspective, the schemes of muzara'a and musaqa can be applied to the financing of agricultural inputs for a specified period of time. In the basic context, the bank will provide funds for the agricultural investments, meanwhile the labour is provided by the farmer. Therefore, in this context, muzara'a and musaqa contracts can be used for obtaining seeds, fertilizers and pesticides along with the needs for the irrigation, storage and marketing of the agricultural commodities.

Alternatively, there is also a possibility for the bank to be a landlord. The bank could first buy the land and then give it to the potential farmer to cultivate according to the aPLS principle. In this case, an Islamic bank plays the role of landowner directly and has a partnership with the farmers. However, these schemes will need not only to employ the principles of al-muzara'a and al-musaqa themselves, but will also involve some other Islamic principles like al-ijarah al-muntahia bi-tamlik, al-murabahah and bay al-salam. For instance, currently, the Islamic banking institutions are not implementing only one-sided al-mudaraba as in classical theory, but incline more to two-tiered al-mudaraba. The banks accumulate deposits from their customers and invest them with third parties based on this principle. Hence, it is relevant to use the principles of al-muzara'a and al-musaqa with proper adjustments from financial experts to make them practical transactions in Islamic banking and financial institutions. Therefore, defining particular steps would necessitate input from many parties, both academicians and practitioners.

\section{Conclusion}

In conclusion, it is apparent that the one-off subsidies from the Department of Agriculture in Malaysia to assist farmers in developing their agricultural land are really beneficial in the short term, i.e., during the first cycle of cultivation. Based on the in-depth interviews, most of farmers in the survey areas said that their income is increasing after getting the subsidies from the government. However, it was found from the case study that many farmers cannot gain enough profit or capital to become independent for the second cycle of cultivation. This will result in their land being abandoned and the initial subsidies will have been wasted.

Furthermore, agricultural land development is a multifarious course. No single agency may success in raising the living standard of the rural communities. A number of agencies such as local governments, national agencies, financial institutions, local leadership need to take the appropriate steps to fight rural poverty. Thus, Islamic banks can play a vital role but they need support in the legal, social and cultural fields.

Therefore, based on the case study in Malaysia, Islamic agricultural financing is really necessary at this point and the agricultural product and loss sharing (aPLS) scheme based on the principles of al-muzara'a and al-musaqa can be proposed here. This is because we learned from the interviews with farmers that they are reluctant to apply for loans from financial institutions. In the aPLS scheme, the financial institution will be considered as an active partner with the farmers and share the agricultural risks and also share in the profit or loss.

Another important issue regarding farmers' lives in Malaysia concerns the non-cash elements in their daily lives. This is opposed to the financial institutions which usually deal with cash transactions in their business. From the case study in the survey areas, it was observed that farmers commonly used the produce from their farm for their daily food consumption and this is not included when calculating their accounts or their monthly income. Therefore, the financial institutions in Malaysia have to have more consideration for the non-cash elements in the farmers' lives. 
We can summarize by stating that the potential for the implementation of Islamic principles in the development of agricultural land in Malaysia is really huge. This can be seen through the demand from the farmers and also the strength availability of financial institutions in Malaysia like Agro Bank for offering agricultural financing based on Islamic principles. Consequently, the government needs to develop the appropriate Islamic financial infrastructure which includes regulation, supervision, compliance, marketing, and incentives either for the institutions or for the farmers themselves.

\section{References}

Az-Zuhayli, W. (2006). The juridical meaning of Riba. Interest in Islamic Economics: Understanding Riba. Oxon: Routledge.

Borhan, J. T., \& Ab Aziz, M. R. (2009). Agriculture Financing in Islamic Banking: An Introduction. In Presented at the International Seminar on Muamalat, Islamic Economics and Finance, Bangi, Malaysia.

Braschler, J. (2006). Microfinance in Islamic Society.

Buang, A., \& Suryandari, R. Y. (2011). Dasar Wawasan Negara dan prospek pembangunan petani kecil Melayu. Geografia-Malaysian Journal of Society and Space, 7(2), 55-64.

Bubna, A., \& Chowdhry, B. (2010). Franchising Microfinance. Review of Finance, 14(3), 451-476. http://dx.doi. org/10.1093/rof/rfp005

Chapra, M. U. (2002). Alternative visions of international monetary reform. Islamic Banking and Finance, 219. http://dx.doi.org/10.4337/9781843765318.00018

Chapra, M. U., \& Chapra, M. U. (1992). Islam and the economic challenge. Leicester: Islamic foundation.

Chew, T. A. (1991). Share contracts in Malaysian rubber smallholdings. Land economics, 85-98. http://dx.doi.org $/ 10.2307 / 3146488$

Donaldson, W. J. (2000). Sharecropping in the Yemen: A study of Islamic theory, custom, and pragmatism (Vol. 13). Brill.

Fredericks, L. J., \& Wells, R. J. G. (1978). Some aspects of tenancy reform measures in Southeast Asia. Asian Survey, 644-658. http://dx.doi.org/10.2307/2643231

Gulaid, M. A. (1995). Financing Agriculture Through Islamic Modes and Instruments: Practical Scenarios and Applicability (pp. 5-15). Islamic Research and Training Institute, Islamic Development Bank.

Hailani, M. T., \& Sanep, A. (2009). Aplikasi Fiqh Muamalat dalam Sistem Kewangan Islam. Shah Alam: UPENA.

Haughton, J. H. (1983). Rural development in peninsular Malaysia: The case of the single-crop rice cultivators (Doctoral dissertation, Harvard University).

Horii, K. (1972). The Land Tenure System of Malay Padi Farmers. The Developing Economies, 10(1), 45-73. http://dx.doi.org/10.1111/j.1746-1049.1972.tb00267.x

Huang, Y. (1975). Tenancy patterns, productivity, and rentals in Malaysia. Economic Development and Cultural Change, 703-718. http://dx.doi.org/10.1086/450834

Hughes, D. W. (1986). Financing the agricultural sector: Future challenges and policy alternatives. Westview special studies in agriculture science and policy (USA).

Khan, M. F. (1995). Essays in Islamic economics (Vol. 19). Islamic Foundation.

Muda, M. N. (2010). Interview, Head of Islamic Banking Division. Agro Bank, Kuala Lumpur, 13 May 2010, 9.30am.

Obaidullah, M., \& Latiff, H. S. H. A. (2008). Islamic finance for micro and medium enterprises. Islamic Finance for Micro and Medium Enterprises. Islamic Research and Training Institute, Islamic Development Bank and Centre for Islamic Banking, Finance and Management, Universiti Brunei Darussalam, Darussalam, 1-13.

Quraishi, A. (1946). Islam and the Theory of Interest. Ashraf Publication, Lahore.

Rahman, A. R. A., \& Rahim, A. (2007). Islamic microfinance: A missing component in Islamic banking. Kyoto Bulletin of Islamic Area Studies, 1(2), 38-53.

Saeed, A. (1996). Islamic banking and interest: A study of the prohibition of Riba and its contemporary interpretation (Vol. 2). New York,NY: Brill. 
Sarker, M. A. A. (1999). Islamic business contracts, agency problem and the theory of the Islamic firm. International Journal of Islamic Financial Services, 1(2), 12-28.

Selvadurai, S. (1972). Padi farming in west Malaysia (p. 83). Malaysia: Ministry of Agriculture and Fisheries.

Senftleben, W. (1978). Background to agricultural land policy in Malaysia. Wiesbaden: Harrassowitz.

Shafiai, M. H. (2012). Islamic Finance for Agricultural Development: Theoretical and Practical Considerations with Special Reference to the Activation of Idle Land in Malaysia. (Unpublised doctoral thesis): Graduate School of Asian and African Area Studies.

Siddiqi, M. N. (1983). Issues in Islamic banking. Islamic Foundation.

Siddiqi, M. N. (1985). Partnership and Profit-Sharing in Islamic Law (Vol. 9). Islamic Foundation.

The Economic Planning Unit 2006. Ninth Malaysia Plan, 2006-2010. Putrajaya: The Economic Planning Unit, Prime Minister's Department.

Tostlebe, A. S. (1957). Preface and table of contents to" Capital in Agriculture: Its Formation and Financing Since 1870". In Capital in Agriculture: Its Formation and Financing Since 1870. Princeton University Press.

Usmani, M. T. (1999). The concept of musharakah and its application as an Islamic method of financing. Arab Law Quarterly, 14(3), 203-220. http://dx.doi.org/10.1163/026805599125826435

Uzair, M. (1955). An Outline of Interestless Banking. Raihan Publications.

Wong, L. C. (2007, January). Development of Malaysia's Agricultural Sector: Agriculture as an Engine of Growth? In Presented at the ISEAS 'Conference on the Malaysian Economy: Development and Challenges (Vol. 25, p. 26).

\section{Copyrights}

Copyright for this article is retained by the author(s), with first publication rights granted to the journal.

This is an open-access article distributed under the terms and conditions of the Creative Commons Attribution license (http://creativecommons.org/licenses/by/3.0/). 